\title{
Declines in traditional marine food intake and vitamin $D$ levels from the 1960s to present in young Alaska Native women
}

\author{
Diane M O'Brien ${ }^{1,2, *}$, Kenneth E Thummel ${ }^{3}$, Lisa R Bulkow ${ }^{4}$, Zhican Wang ${ }^{3}$, \\ Brittany Corbin ${ }^{2}$, Joseph Klejka ${ }^{5}$, Scarlett E Hopkins ${ }^{1}$, Bert B Boyer ${ }^{1}$, \\ Thomas W Hennessy ${ }^{4}$ and Rosalyn Singleton ${ }^{4,6}$ \\ ${ }^{1}$ Center for Alaska Native Health Research, Institute of Arctic Biology, University of Alaska, PO Box 757000, \\ Fairbanks, AK 99775-7000, USA: ${ }^{2}$ Department of Biology and Wildlife, University of Alaska, Fairbanks, AK, USA: \\ ${ }^{3}$ School of Pharmacy, University of Washington, Seattle, WA, USA: ${ }^{4}$ Arctic Investigations Program, Division of \\ Preparedness and Emerging Infections, National Center for Emerging and Zoonotic Infectious Diseases, Centers for \\ Disease Control and Prevention, Anchorage, AK, USA: ${ }^{5}$ Yukon Kuskokwim Health Corporation, Bethel, AK, USA: \\ ${ }^{6}$ Alaska Native Tribal Health Consortium, Division of Community Health Services, Anchorage, AK, USA
}

Submitted 21 December 2015: Final revision received 23 May 2016: Accepted 15 June 2016: First published online 28 July 2016

\begin{abstract}
Objective: To measure the trends in traditional marine food intake and serum vitamin D levels in Alaska Native women of childbearing age (20-29 years old) from the 1960 s to the present.

Design: We measured a biomarker of traditional food intake, the $\delta^{15} \mathrm{~N}$ value, and vitamin D level, as 25-hydroxycholecalciferol $\left(25(\mathrm{OH}) \mathrm{D}_{3}\right)$ concentration, in 100 serum samples from 20-29-year-old women archived in the Alaska Area Specimen Bank, selecting twenty-five per decade from the 1960s to the 1990s. We compared these with measurements of red-blood-cell $\delta^{15} \mathrm{~N}$ values and serum $25(\mathrm{OH}) \mathrm{D}_{3}$ concentrations from 20-29-year-old women from the same region collected during the 2000s and 2010s in a Center for Alaska Native Health Research study.

Setting: The Yukon Kuskokwim Delta region of south-west Alaska.

Subjects: Alaska Native women ( $n$ 319) aged 20-29 years at the time of specimen collection.

Results: Intake of traditional marine foods, as measured by serum $\delta^{15} \mathrm{~N}$ values, decreased significantly each decade from the 1960s through the 1990s, then remained constant from the 1990 s through the present $\left(F_{5,306}=77 \cdot 4, P<0 \cdot 0001\right)$. Serum vitamin D concentrations also decreased from the 1960 s to the present $\left(F_{4,162}=26 \cdot 1, P<0 \cdot 0001\right)$.

Conclusions: Consumption of traditional marine foods by young Alaska Native women dropped significantly between the 1960s and the 1990s and was associated with a significant decline in serum vitamin D concentrations. Studies are needed to evaluate the promotion of traditional marine foods and routine vitamin D supplementation during pregnancy for this population.

Keywords
Nutrition transition
Rickets
25 -Hydroxycholecalciferol concentration
$\delta^{15} \mathrm{~N}$ value
Stable isotope ratios
Arctic health
Circumpolar health
\end{abstract}

The contribution of a changing diet to increasing rates of chronic disease among Alaska Native people has long been a focus of research investigation ${ }^{(1-3)}$. We developed a particular interest in the role that changing diets of childbearing women may have on vitamin D deficiency and rickets in children after a recent study reported a high incidence of rickets in Alaska Native children relative to other populations ${ }^{(4)}$, following a report of rickets diagnoses in Alaska in the $1990 \mathrm{~s}^{(5)}$. Of the confirmed rickets diagnoses, $63 \%$ were in children under 1 year of age ${ }^{(4)}$, suggesting the importance of maternal vitamin D status. Previous dietary evaluations in Alaska
Native people showed higher vitamin D intake in Alaska Native people eating a traditional subsistence $\operatorname{diet}^{(2,3,6,7)}$, mirroring trends found in the Canadian $\operatorname{Arctic}^{(8-10)}$ and Greenland ${ }^{(11-13)}$.

A major survey of Alaska Native diets conducted in the late $1950 \mathrm{~s}$ found that traditional foods contributed approximately $44 \%$ of energy and $72 \%$ of protein to the diet of adults in eleven communities spanning three regions of Alaska ${ }^{(14)}$. Currently Alaska Native diets include a much larger proportion of store-bought (hereafter, 'market') foods, averaging approximately $80 \%$ of energy in the Yukon Kuskokwim (YK) Delta region ${ }^{(2,3,15)}$. 
While the fact that diets have changed is evident, the time course of change from more traditional to more marketbased diets has not been documented, as diet records spanning multiple decades and collected using consistent methods do not exist. Our group has recently validated chemical biomarkers of traditional and market food intake in a Yup'ik population in the YK Delta region of south-west Alaska, which allow retrospective dietary studies using banked specimens ${ }^{(16-18)}$. These biomarkers are based on naturally occurring differences in stable isotope ratios among foods ${ }^{(16)}$ and can be measured in serum, plasma or red blood cells (RBC) ${ }^{(19)}$. The nitrogen isotope ratio $\left({ }^{15} \mathrm{~N}:{ }^{14} \mathrm{~N}\right.$, expressed relative to a standard as $\delta^{15} \mathrm{~N}$ values) is high in fish and marine mammals ${ }^{(16)}$, and provides a measure of traditional food intake because fish and marine mammals contribute over $75 \%$ of total traditional food energy in that population ${ }^{(2)}$.

In the present study we tested the hypothesis that consumption of traditional marine foods by Alaska Native women of childbearing age has declined from the 1960s to the present, and that this decline is associated with reduced serum 25-hydroxycholecalciferol $\left(25(\mathrm{OH}) \mathrm{D}_{3}\right)$. We analysed serum samples collected during the 1960s, 1970s, 1980s and 1990s and stored in the Alaska Area Specimen Bank (AASB $)^{(20)}$ for biomarkers of traditional marine diet $\left(\delta^{15} \mathrm{~N}\right.$ values $)$ and $25(\mathrm{OH}) \mathrm{D}_{3}$. All samples were collected from women aged 20-29 years in the YK Delta region of south-western Alaska. To extend the record through to the present we used data from the same region that were collected by the University of Alaska Fairbanks (UAF) Center for Alaska Native Health Research (CANHR) in the 2000s and 2010s. We focused on the YK Delta region because it is well represented across all decades in the AASB and also has a modern data set for comparison. Our goal was to evaluate changes in traditional marine food intake over time, to understand potential contributors to the recent higher risk for rickets and vitamin D deficiency among YK Delta and other Alaska Native children.

\section{Methods}

\section{Study population}

Serum specimens from 1960-1999 were provided by the AASB, which is maintained at the Centers for Disease Control and Prevention's Arctic Investigation Program and overseen by the AASB committee ${ }^{(20)}$. The present study used 100 serum samples collected from women of childbearing age in the YK Delta in the 1960s, 1970s, 1980s and 1990s, and stored at -20 to $-30^{\circ} \mathrm{C}$ in the AASB. The samples were drawn originally for eight historical village-wide research studies on a variety of illnesses during the 1960s and 1970s, and for hepatitis B screening and follow-up studies (1980s, 1990s). Most of these were region-wide studies open to all village residents, making it unlikely that there was a bias towards or against a more traditional lifestyle. The samples were evenly divided with twenty-five from each of the decades, with similar numbers from coastal and upriver communities for each decade. These sample sizes were chosen to give $>90 \%$ power to detect inter-decade differences in serum $\delta^{15} \mathrm{~N}$ values of $1.0 \%$, given an expected within-group SD of $1 \cdot 1 \%{ }^{(16)}$. All samples were from women aged $20-29$ years at the time of blood draw, evenly split between 20-24 years of age and 25-29 years of age. All samples tested were drawn between September and November to control for seasonal variation. The selected specimens were randomly drawn from the pool of available serum specimens that met the above requirements. Serum samples were used for analysis of both the $\delta^{15} \mathrm{~N}$ value and $25(\mathrm{OH}) \mathrm{D}_{3}$ concentration, as described below. The $\delta^{15} \mathrm{~N}$ value has been validated as a measure of traditional marine food dietary intake in the YK Delta region in three ways: (i) by comparison with self-reported intake (Pearson's $r>0.5)^{(16)}$; (ii) by comparison with RBC EPA, a marinederived fatty acid that is a biomarker for EPA intake (Pearson's $r>0.8)^{(17)}$; and (iii) by demonstrating that associations with disease risk mirror those found using RBC EPA ${ }^{(18)}$

Comparison measurements from 2000-2009 and 2010-present were provided by the CANHR, which has been conducting health research in the YK Delta region of Alaska since $2003^{(21)}$. For dietary biomarker data, we used RBC $\delta^{15} \mathrm{~N}$ values collected in the 2000s and 2010s. Where multiple blood samples had been collected from an individual woman, we used data from the most recent blood draw. Data were available for 219 Alaska Native women aged 20-29 years. From the 2000s, there were data from 110 women, fifty-nine in coastal communities and fifty-one in upriver communities. From the 2010s, there were data from 109 women, sixty-three in coastal communities and forty-six women in upriver communities. Measurements of serum $25(\mathrm{OH}) \mathrm{D}_{3}$ concentration were available for most of the samples from the 2010s (seventythree women, thirty-five in coastal communities and thirty-eight in upriver communities), but were not available from 2000-2009. There were low numbers of CANHR samples drawn between September and November in coastal communities in the 2010s; therefore, CANHR data included all months of sample collection (primarily late spring and early winter) so that the distribution of community locations would be similar to the AASB samples. In upriver communities, the mean $25(\mathrm{OH}) \mathrm{D}_{3}$ concentration between September and November 2010 was $4.3 \mathrm{ng} / \mathrm{ml}$ higher than when all collection months were included.

The relationship between $\delta^{15} \mathrm{~N}$ values measured in serum and RBC was tested using samples from eighteen CANHR participants for whom both serum and RBC $\delta^{15} \mathrm{~N}$ values were available ${ }^{(22)}$. For this sub-aim, participants were $56 \%$ female and ranged in age from 14 to 56 years old. 


\section{Stable isotope measurements}

Serum and RBC samples were prepared for analysis of nitrogen isotope ratios as described elsewhere ${ }^{(16,22)}$. Briefly, $1.9 \mu \mathrm{l}$ of $\mathrm{RBC}$ and $3.5 \mu \mathrm{l}$ of serum were pipetted into $3.5 \mathrm{~mm} \times 3.75 \mathrm{~mm}$ tin capsules (Costech) held in custom-machined aluminium ninety-six-well plates and autoclaved to remove blood-borne pathogen risk $^{(23)}$. Samples were dried at $60^{\circ} \mathrm{C}$ and tin capsules were crushed into balls for loading into an autosampler. Isotope ratios were determined at the UAF Alaska Stable Isotope Facility by continuous-flow isotope ratio MS, using a Costech ECS4010 Elemental Analyzer (Costech Analytical Technologies, Inc.) interfaced to a Thermo Delta $\mathrm{V}$ isotope ratio mass spectrometer via the Conflo IV interface (Thermo Fisher Scientific). Isotope ratios are conventionally expressed as delta values, which give the abundance of heavy isotope relative to an international standard, as follows: $\delta^{15} \mathrm{~N}=\left\{\left[\left({ }^{15} \mathrm{~N}:{ }^{14} \mathrm{~N}\right)_{\text {sample }}-\left({ }^{15} \mathrm{~N}:{ }^{14} \mathrm{~N}\right)_{\text {standard }}\right] /\right.$ $\left.\left[\left({ }^{15} \mathrm{~N}:{ }^{14} \mathrm{~N}\right)_{\text {standard }}\right]\right\} \times 1000 \%$, in which the standard is atmospheric nitrogen (air, ${ }^{15} \mathrm{~N}:{ }^{14} \mathrm{~N}=0.0036765$ ). Analytical precision was assessed as the SD of a laboratory working standard (peptone), which was run at the beginning and end of each batch of analyses and after every tenth sample. Precision was within $0 \cdot 2 \%$. The isotope ratio ${ }^{15} \mathrm{~N}:{ }^{14} \mathrm{~N}$ is highly stable over time ${ }^{(19)}$ and thus can be measured in archived samples.

\section{Vitamin D measurements}

Quantification of $25(\mathrm{OH}) \mathrm{D}_{3}$ in human sera was achieved by protein precipitation, liquid-liquid extraction, derivatization and LC-MS/MS analysis, following a previously described general procedure ${ }^{(24)}$. Briefly, the calibration curve was generated by a series of dilutions of a standard mixture containing $100 \mathrm{ng} 25(\mathrm{OH}) \mathrm{D}_{3} / \mathrm{ml}$ prepared in vitamin D-free human serum (Golden West Biologicals). After thawing, human sera $(0.1 \mathrm{ml})$ or a standard curve set were accurately added into $2 \mathrm{ml}$ capped PPE microcentrifuge tubes and spiked with $d_{6}-25(\mathrm{OH}) \mathrm{D}_{3}(5 \mathrm{ng})$ internal standard. Acetonitrile $(0.2 \mathrm{ml}, \mathrm{v} / \mathrm{v} 2: 1)$ was added to precipitate proteins. After centrifugation (12000 g, $5 \mathrm{~min}$ ), the supernatant was transferred to capped glass tubes and concentrated under a nitrogen stream prior to extraction with ethyl acetate $(3 \mathrm{ml})$. The organic layer was isolated after centrifugation and dried under a stream of nitrogen. Samples were then derivatized with $1 \mathrm{mg}$ 4-phenyl-1,2,4-triazoline-3,5-dione/ml $(100 \mu \mathrm{l})$ in acetonitrile for $1 \mathrm{~h}$ at room temperature, in the dark. The derivatized samples were transferred to a new glass tube and dried under a stream of nitrogen. The solid residue was reconstituted in $30 \% \mathrm{v} / \mathrm{v}$ acetonitrile $(60 \mu \mathrm{l})$ and transferred to $200 \mu \mathrm{l}$ glass inserts for LC-MS/MS analysis. Ultrahigh-performance LC was performed on a Hypersil Gold $(2.1 \mathrm{~mm} \times 100 \mathrm{~mm}, 1.9 \mu \mathrm{m})$ column (Thermo Scientific) using methanol (B) $/ 0 \cdot 1 \% \mathrm{v} / \mathrm{v}$ formic acid in water (A) as a mobile phase. The flow rate was $0.25 \mathrm{ml} / \mathrm{min}$ with a solvent gradient (v/v) as follows: $60 \%$ solvent B holding for $1 \mathrm{~min}$, then to $64 \% \mathrm{~B}$ over $19 \mathrm{~min}$, holding at $64 \% \mathrm{~B}$ for $0.5 \mathrm{~min}$, increasing to $90 \% \mathrm{~B}$ in $3 \mathrm{~min}$ and then holding for another $1 \mathrm{~min}$, decreasing back to $60 \% \mathrm{~B}$ until $25 \mathrm{~min}$, followed by $3 \mathrm{~min}$ for equilibrium back to initial conditions. MS/MS analysis was carried out using positive mode electrospray ionization on an Agilent 6410 QQQ equipped with a UPLC1290 infinity system (Agilent Technologies). Multiple Reaction Monitoring channels of $m / z 558 \rightarrow 298$ and $564 \rightarrow 298$ were set to detect $25(\mathrm{OH}) \mathrm{D}_{3}$ and $d_{6}-25(\mathrm{OH}) \mathrm{D}_{3}$, respectively. This assay was validated in-house using the National Institute of Standards and Technology (NIST) standard reference material for vitamin D metabolites (SRM972), which contains four low-to-high levels of $25(\mathrm{OH}) \mathrm{D}_{3}$ in frozen human serum. All the measured $25(\mathrm{OH}) \mathrm{D}_{3}$ concentrations at each of these four pre-specified levels were within $15 \%$ of the $\mathrm{CV}$, as compared with the reference concentrations provided with the NIST standard. In addition, inter-day assay variability was assessed by daily analysis of two quality control samples that had been prepared in replicate prior to the start of the study and stored at $-80^{\circ} \mathrm{C}$. All measured concentrations of the quality control samples differed by $<10 \%$ from the expected nominal (15 and $25 \mathrm{ng} / \mathrm{ml}$ ) concentrations.

The present study involved the analysis of serum samples that had been archived for up to 55 years. Other investigators have demonstrated the stability of $25(\mathrm{OH}) \mathrm{D}_{3}$ in frozen serum/plasma samples kept for extended periods of time ${ }^{(25-27)}$.

\section{Statistical analyses}

Statistical analyses were performed using the statistical software packages JMP version 11 and Stata version 10 . We tested the association between $\delta^{15} \mathrm{~N}$ values in RBC and serum using linear regression, and used the results to convert $\delta^{15} \mathrm{~N}$ values of CANHR RBC samples to equivalent values for serum. Those values were used for comparison with AASB sample data.

We tested whether $\delta^{15} \mathrm{~N}$ values and $25(\mathrm{OH}) \mathrm{D}_{3}$ concentrations changed between the decades using ANOVA, with independent variables=decade, coastal (yes/no) and age class (20-24 years/25-29 years), and all second-order interactions. Non-significant interaction terms were removed from the final models. Pairwise differences among decades were tested using Tukey's honest significant differences at $P<0 \cdot 05$. Normality of residuals was tested using the Shapiro-Wilks test, and serum $\delta^{15} \mathrm{~N}$ values and vitamin $\mathrm{D}$ were log-transformed for parametric analyses to improve normality. The effect of location (coastal/inland) stratified by decade was tested with Student's $t$ test.

The association between serum vitamin $\mathrm{D}$ and $\delta^{15} \mathrm{~N}$ values was tested using Spearman rank correlation. We report the number/percentage of participants with serum $25(\mathrm{OH}) \mathrm{D}_{3}$ concentrations of $<12 \mathrm{ng} / \mathrm{ml}$ and $12-20 \mathrm{ng} / \mathrm{ml}$, as these are highlighted by the Institute of Medicine as meaningful thresholds for vitamin D status in their 2011 report $^{(28,29)}$. 


\section{Results}

Serum $\delta^{15} \mathrm{~N}$ values were strongly and linearly related to RBC $\delta^{15} \mathrm{~N}$ values $\left(R^{2}=0.9, P<0.0001\right)$, with an average offset of $+1.5 \%$ (Fig. 1). A correction of $+1.5 \%$ was applied to the RBC $\delta^{15} \mathrm{~N}$ values from the CANHR study to convert them to comparable serum $\delta^{15} \mathrm{~N}$ values, for comparison with the AASB serum samples.

Intake of traditional marine foods, as measured by serum $\delta^{15} \mathrm{~N}$ values, decreased significantly each decade from the 1960s through the 1990s, then remained constant from the 1990s through the present $\left(F_{5,306}=77 \cdot 4\right.$, $P<0.0001$; Table 1, Fig. 2(a)). Women aged 25-29 years had slightly higher $\delta^{15} \mathrm{~N}$ values than women aged

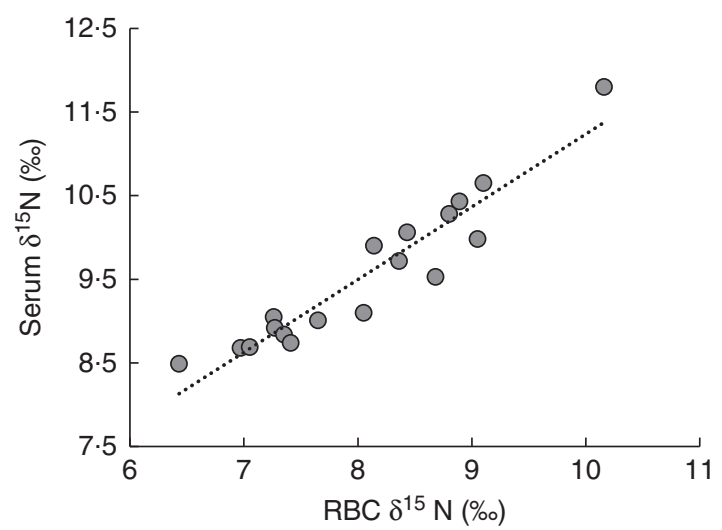

Fig. 1 Linear relationship between red-blood-cell (RBC) $\delta^{15} \mathrm{~N}$ values and serum $\delta^{15} \mathrm{~N}$ values $\left(R^{2}=0.90\right)$, from eighteen participants in the Center for Alaska Native Health Research study (ten females, eight males, aged 14-56 years)
20-24 years $\left(F_{1,306}=5 \cdot 5, \quad P=0.02\right)$. Women from coastal communities had higher $\delta^{15} \mathrm{~N}$ values than women from inland communities $\left(F_{1,306}=35.4, P<0.0001\right)$ and there was a significant interaction between community location and decade $\left(F_{5,306}=5 \cdot 3, P=0.0001\right.$; Fig. 2(a)). When $\delta^{15} \mathrm{~N}$ values were analysed by decade, the effect of community location was greatest in the 1960s $(t=-5 \cdot 7$, $P<0.0001)$, but also significant in the 2000s $(t=-2 \cdot 8$, $P=0.006)$ and the 2010s $(t=-2 \cdot 2, P=0.03$; Fig. 2(a)). There was no significant interaction between community location and age class or between decade and age class.

Serum $25(\mathrm{OH}) \mathrm{D}_{3}$ concentrations also decreased from the 1960s to the present $\left(F_{4,162}=26 \cdot 1, P<0 \cdot 0001\right)$. Serum $25(\mathrm{OH}) \mathrm{D}_{3}$ concentrations in the $1980 \mathrm{~s}, 1990 \mathrm{~s}$ and $2010 \mathrm{~s}$ were lower than in the 1960s and 1970s, but concentrations in the 1980s, 1990s and 2010s did not differ significantly from each other (Table 1, Fig. 2(b)). Serum $25(\mathrm{OH}) \mathrm{D}_{3}$ concentrations did not differ by age $\left(F_{1,162}=0 \cdot 6\right.$, $P=0.42)$ or by community location $\left(F_{1,162}=0.003, P=0.96\right)$; however, there was a significant interaction between community location and decade $\left(F_{4,162}=2 \cdot 8, \quad P=0.029\right.$; Table 1, Fig. 2(b)). When analysed by decade, the effect of community location was significant only in the 2010 s and, unlike the $\delta^{15} \mathrm{~N}$ value, $25(\mathrm{OH}) \mathrm{D}_{3}$ concentration was higher in inland communities $(t=3.43, \quad P<0.001$; Fig. 2(b)). In the 1960s and 1970s, none of the women had vitamin D concentrations $\leq 20 \mathrm{ng} / \mathrm{ml}$, whereas in the $1980 \mathrm{~s}$, 1990 s and 2010s, 24\%, 28\% and $27 \%$ of the women had vitamin D concentrations $\leq 20 \mathrm{ng} / \mathrm{ml}$, and $2 \%, 0 \%$ and $4 \%$ had vitamin D concentrations $<12 \mathrm{ng} / \mathrm{ml}$, respectively (Table 1, Fig. 2(b)).

Table 1 Serum $\delta^{15} \mathrm{~N}$ values and 25-hydroxycholecalciferol $\left(25(\mathrm{OH}) \mathrm{D}_{3}\right)$ concentrations, by decade, in 20-29-year-old women from the Yukon Kuskokwim Delta region of south-west Alaska

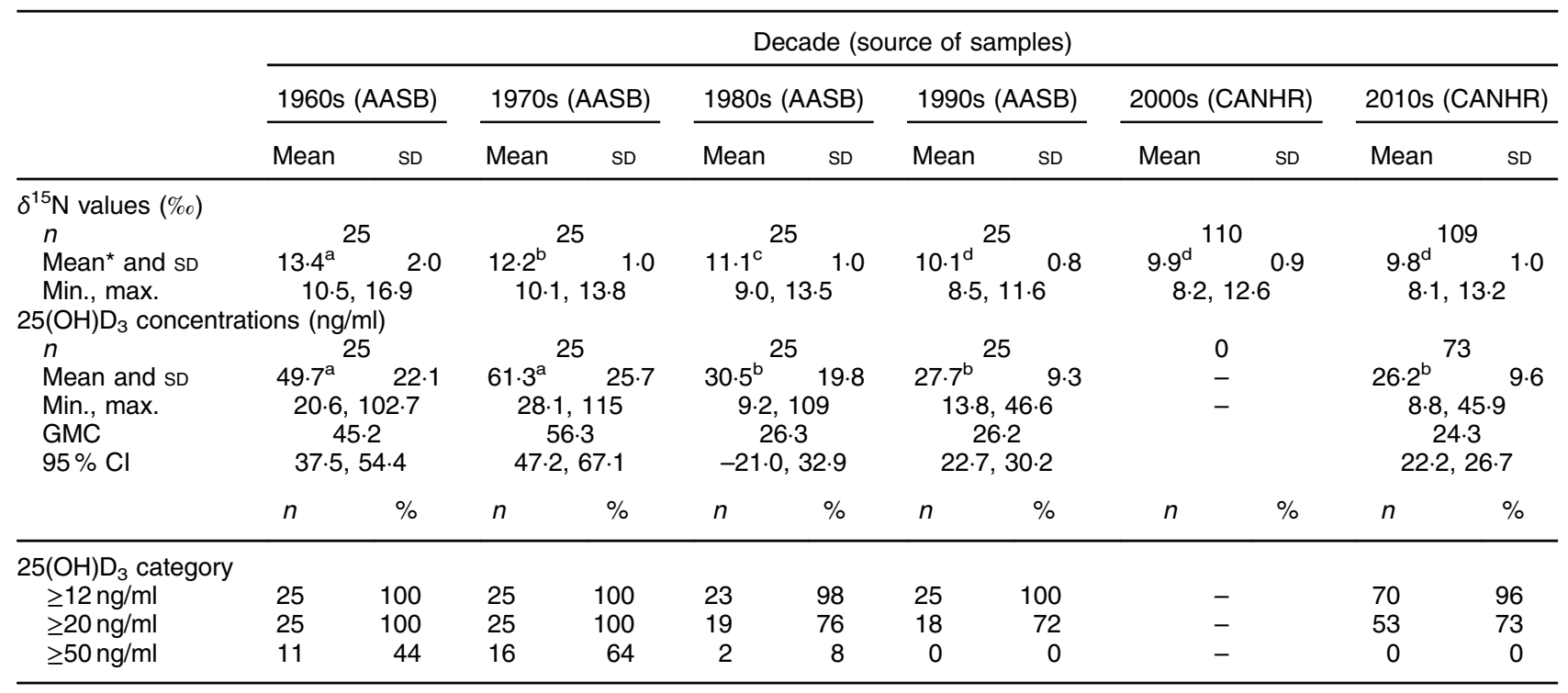

AASB, Alaska Area Specimen Bank ${ }^{(20)}$; CANHR, Center for Alaska Native Health Research Study ${ }^{(21)}$; min., minimum; max., maximum; GMC, geometric mean concentration.

${ }_{\mathrm{a}, \mathrm{b}, \mathrm{c}, \mathrm{d}}$ Mean values with unlike superscript letters were statistically different in post hoc comparisons (Tukey's honest significant differences; $P<0.05$ ).

${ }^{*} \delta^{15} \mathrm{~N}$ values were log-transformed for statistical analysis; however, geometric means differed from means by $<0.2 \%$, thus here only means and sD are presented. 

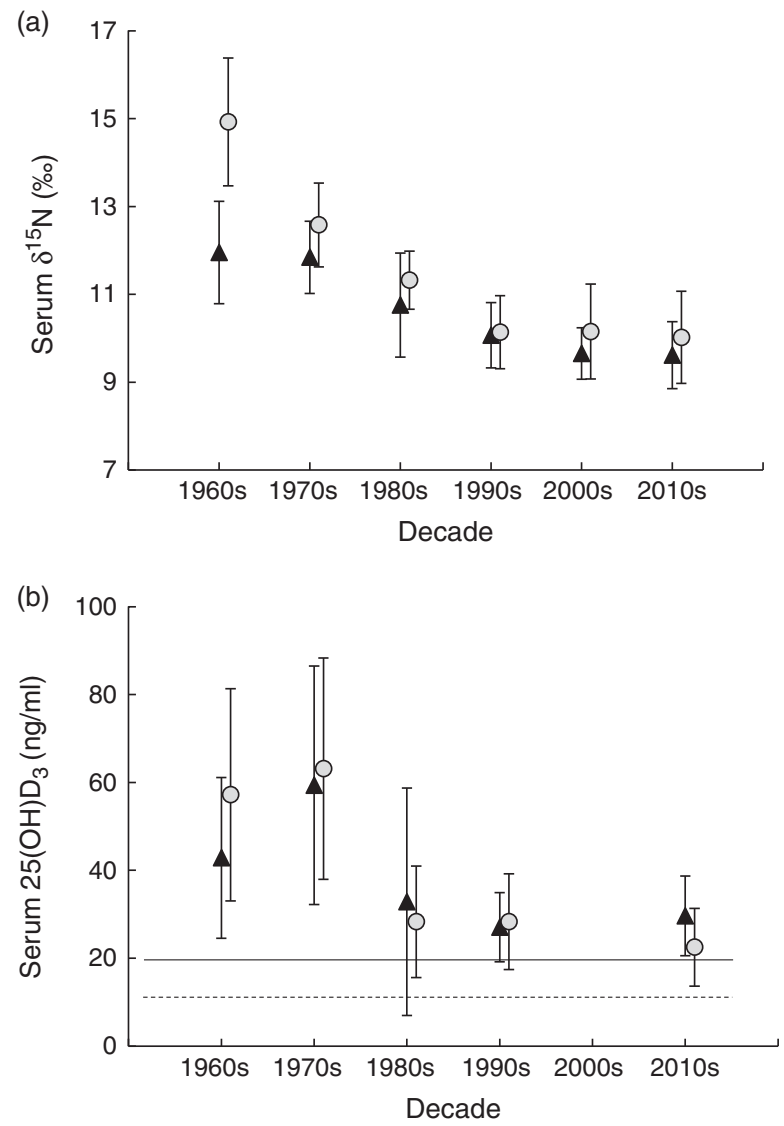

Fig. 2 Differences in (a) mean serum $\delta^{15} \mathrm{~N}$ values and (b) mean serum 25-hydroxycholecalciferol $\left(25(\mathrm{OH}) \mathrm{D}_{3}\right)$ concentrations, with their standard deviations represented by vertical bars, by decade and community location ( $\boldsymbol{\Lambda}$, upriver; $\mathrm{O}$, coastal), in 20-29-year-old women from the Yukon Kuskokwim Delta region of south-west Alaska. Samples from 1960-1999 derive from the Alaska Area Specimen Bank ${ }^{(20)}$, samples from 2000-present derive from the Center for Alaska Native Health Research Study ${ }^{(21)}$. In (b), - indicates serum $25(\mathrm{OH}) \mathrm{D}_{3}$ concentration of $20 \mathrm{ng} / \mathrm{ml}$ and - - - - - indicates serum $25(\mathrm{OH}) \mathrm{D}_{3}$ concentration of $12 \mathrm{ng} / \mathrm{ml}$ (meaningful thresholds for vitamin D status according to the Institute of Medicine ${ }^{(28,29)}$ )

Serum $25(\mathrm{OH}) \mathrm{D}_{3}$ concentrations were significantly associated with serum $\delta^{15} \mathrm{~N}$ values, both in the complete data set (Spearman $\rho=0.61, P<0.0001$; Fig. 3) and by decade (Table 2, Fig. 3).

\section{Discussion}

Traditional marine food intake, as assessed by the serum $\delta^{15} \mathrm{~N}$ value, declined linearly from the 1960s through the 1990 s in young (20-29-year-old) Alaska Native women and then remained constant from the 1990s through the present. Vitamin D levels, measured as serum $25(\mathrm{OH}) \mathrm{D}_{3}$ concentrations, also declined significantly between the 1960s-1970s and the 1980s-2010s, and were associated with assessed intake of traditional marine foods both within and across decades. These data demonstrate a

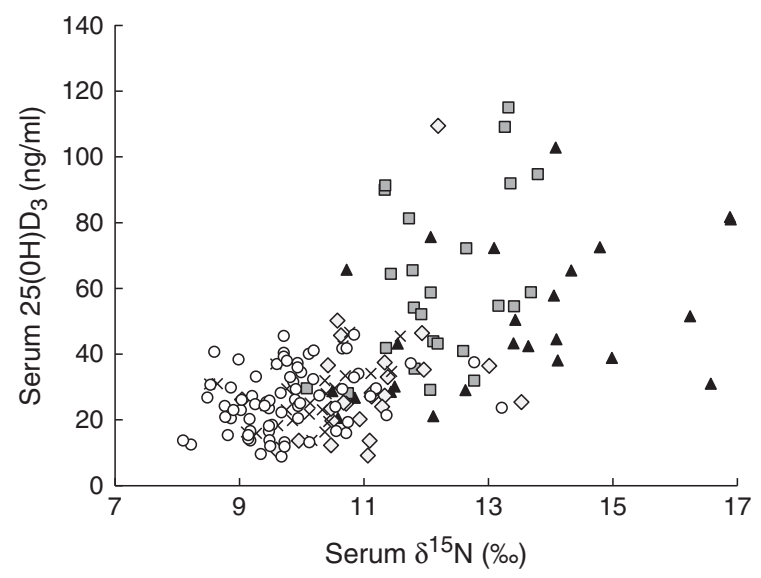

Fig. 3 Association between serum 25-hydroxycholecalciferol $\left(25(\mathrm{OH}) \mathrm{D}_{3}\right)$ concentrations and serum $\delta^{15} \mathrm{~N}$ values, by decade

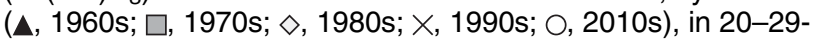
year-old-women from the Yukon Kuskokwim Delta region of south-west Alaska. Samples from 1960-1999 derive from the Alaska Area Specimen Bank ${ }^{(20)}$, samples from 2000-present derive from the Center for Alaska Native Health Research Study ${ }^{(21)}$

Table 2 Spearman rank correlation of serum $\delta^{15} \mathrm{~N}$ values and 25-hydroxycholecalciferol concentrations, by decade, in 20-29year-old women from the Yukon Kuskokwim Delta region of southwest Alaska

\begin{tabular}{lcc}
\hline & $\begin{array}{c}\text { Spearman rank } \\
\text { correlation }(\rho)\end{array}$ & $P$ value \\
\hline $1960 \mathrm{~s}$ & 0.53 & 0.006 \\
$1970 \mathrm{~s}$ & 0.35 & 0.086 \\
$1980 \mathrm{~s}$ & 0.45 & 0.024 \\
$1990 \mathrm{~s}$ & 0.49 & 0.013 \\
$2010 \mathrm{~s}$ & 0.33 & 0.004 \\
Total & 0.61 & $<0.0001$ \\
\hline
\end{tabular}

nutrition transition from traditional foods to market foods in Alaska Native people. Other studies have inferred this transition $^{(1-3,30)}$; however, our approach of measuring a dietary biomarker and vitamin $\mathrm{D}$ in archived historical specimens provides a quantitative temporal record, covering a period of nearly 60 years. These declines in traditional food intake and vitamin $\mathrm{D}$ have significant implications for public health, as none of the women studied had vitamin D concentrations $\leq 20 \mathrm{ng} / \mathrm{ml}$ in the 1960 s and 1970s, whereas 24-28\% did in the 1980s, 1990s and 2010s. By some criteria, these concentrations are considered vitamin D insufficient ${ }^{(28)}$, whereas by others they are considered vitamin $\mathrm{D}$ deficient ${ }^{(31)}$; either way, they demonstrate a decrease in vitamin D status of these women over time.

It is likely that the sharp decline in traditional marine food intake by women of childbearing age from the 1960s to the 1990s in the YK Delta is one of the main factors causing significant declines in vitamin D concentrations in this sample of women, similar to recent findings from Greenland $^{(12)}$. This dietary transition may also have been a factor contributing to increasing reports of rickets in Alaska Native children starting in the $1990 \mathrm{~s}^{(5)}$. 
Many traditional subsistence foods provide an excellent and economical source of vitamin $\mathrm{D}^{(2,32)}$, whereas market foods rich in vitamin $\mathrm{D}$ are often expensive, unavailable or not preferred. The importance of traditional dietary intake to vitamin D status of Alaska Native people and people of the Canadian Arctic and Greenland has been well documented in recent years ${ }^{(2,3,6,10,33-35)}$. Two recent studies highlight this point for the contemporary Yup'ik population of the YK Delta: one study found that $90 \%$ of self-reported dietary vitamin D intake was from fish ${ }^{(6)}$ and another found that traditional dietary intake (measured as the RBC $\delta^{15} \mathrm{~N}$ value) explained $21 \%$ of inter-individual differences in serum $25(\mathrm{OH}) \mathrm{D}_{3}$ concentration ${ }^{(7)}$. At the latitude of Alaska, pre-cholecalciferol production in the skin essentially ceases from October through March $^{(36-38)}$, making Alaskans and other high-latitude populations particularly dependent on dietary sources of vitamin $\mathrm{D}^{(10,11)}$.

Our group recently described high rates of rickets incidence and hospitalization in Alaska Native children relative to the general US rate ${ }^{(4)}$. Rickets diagnoses dated from the $1990 \mathrm{~s}^{(4,5)}$, when traditional food intake by childbearing aged women in the present study had reached a constant, low value. Given the evidence of low traditional food consumption in childbearing-aged Alaska Native women, vitamin D supplementation may be important in women and infants to prevent infantile rickets. Consistent with this, the American Academy of Pediatrics recommends that regardless of sunlight and food intake, all breast-fed infants/ children and those receiving $<1$ litre of infant formula daily receive vitamin D supplementation of $10 \mu \mathrm{g} / \mathrm{d}$ $(400 \mathrm{IU} / \mathrm{d})^{(39)}$. Although $10 \mu \mathrm{g} / \mathrm{d} \mathrm{d}$ is adequate to prevent rickets in most infants, those born to severely vitamin D-deficient women may develop congenital rickets ${ }^{(40)}$; therefore, a traditional marine diet and vitamin D supplementation to prevent deficiency may be particularly important for pregnant Alaska Native women.

The present study is distinctive for its approach of using archived specimens to create a continuous, 60-year historical record of traditional dietary intake and vitamin $\mathrm{D}$ status in Alaska Native people, which was made possible by the unique tribal-federal partnership of the $\mathrm{AASB}^{(20)}$. While the fact that Alaska Native people are undergoing a nutrition transition is widely inferred ${ }^{(3,15,41)}$, direct evidence of this transition has been lacking, and the timing and trajectory of such a transition in different regions of Alaska have not been documented given the lack of historical dietary records. A number of studies have documented dietary differences between youth and elders $^{(1,2,15,16)}$; however, whether those differences persist throughout the lifespan or whether youth adopt the diet of their elders as they age is not known. We note that biomarker measurements of traditional dietary intake by women aged 20-29 years in the 1960s and 1970s from the current study are similar to those of modern elders in the YK region ${ }^{(7,16)}$. It would be interesting to extend the record to the 1950s and prior, given reports of major dietary change prior to the early $1960 \mathrm{~s}^{(1)}$; however, these dates are not represented in the $\mathrm{AASB}^{(20)}$.

The study has some limitations. The randomly selected AASB samples may not be representative of the population of women 20-29 years of age in the YK Delta during those decades; however, because most were collected during region-wide studies open to all village residents, we believe it is unlikely that there was a sampling bias towards or against women who followed a more traditional lifestyle. Furthermore, because the design takes advantage of sampling from the same population during several successive decades, there is the possibility that bias to the reported serum $25(\mathrm{OH}) \mathrm{D}_{3}$ concentration could be introduced by sample desiccation, as discussed previously ${ }^{(42)}$. The effect would likely have been greatest with the longest storage times and thus may contribute to higher measured $25(\mathrm{OH}) \mathrm{D}_{3}$ concentrations in the oldest samples. We attempted to control for this potential bias by measuring and normalizing the $25(\mathrm{OH}) \mathrm{D}_{3}$ concentration data for serum $\mathrm{Na}$ concentration. Both aberrantly high and low $\mathrm{Na}$ concentrations were measured using a standardized automated clinical laboratory protocol, as reported by others ${ }^{(42)}$. However, some of the oldest serum samples had been stored in glass tubes for a significant period of time and leaching of $\mathrm{Na}$ from the glass into the serum could also have contributed to aberrantly high $\mathrm{Na}$ concentrations. Furthermore, there was particulate (removed by centrifugation) in some of the serum samples after thawing, which could trap $\mathrm{Na}$ and contribute to aberrantly low $\mathrm{Na}$ values, as reported previously ${ }^{(42)}$. Without full confidence in all $\mathrm{Na}$ measurements, we elected to not correct the $25(\mathrm{OH}) \mathrm{D}_{3}$ data set. The $\delta^{15} \mathrm{~N}$ value is not affected by desiccation, as it measures ${ }^{15} \mathrm{~N}:{ }^{14} \mathrm{~N}$, and the fact that it was correlated with serum $25 \mathrm{OHD}_{3}$ across all decades suggests that any sample desiccation that did occur was random. Of note in this regard, the same positive and significant correlation between $\delta^{15} \mathrm{~N}$ and serum $25(\mathrm{OH}) \mathrm{D}_{3}$ was seen in a large contemporary study conducted in the same population, where precautions were taken to avoid desiccation $^{(7)}$.

In summary, we found a linear decline in traditional marine food intake from the 1960s through the 1990s in young (20-29-year-old) Alaska Native women in the YK Delta region of south-west Alaska, concomitant with a drop in serum vitamin D levels. Prior to this decrease, none of these 20-29-year-old women were vitamin D deficient; however, after the decrease (1990s and 2010s) $28 \%$ were vitamin D deficient. Traditional food intake remained low and constant from the 1990s through the present, a period which has also been marked by the appearance of rickets in Alaska Native children ${ }^{(4)}$. Studies to evaluate traditional dietary practices and optimal vitamin $\mathrm{D}$ supplementation during pregnancy to prevent early childhood rickets are needed. 


\section{Acknowledgements}

Acknowledgements: The authors thank Jynene Black for laboratory support; Karen Rudolph and Carolynn DeByle, Arctic Investigations Program, for AASB specimen processing; and Andrea Bersamin for helpful input. Financial support: This work was supported by the National Institutes of Health (K.E.T. and Z.W., grant numbers U01 GM092676 and R01 GM063666; B.B.B., S.E.H. and D.M.O., grant number P30 GM103325); and the UAF Office of Undergraduate Research and Scholarly Activity (D.M.O. and B.C., UAF Summer Undergraduate Research Award). The content of this paper is solely the responsibility of the authors and does not necessarily represent the official views of the National Institutes of Health. Disclaimer: The findings and conclusions in this article are those of the authors and do not necessarily represent the official position of the Centers for Disease Control and Prevention. Conflict of interest: None. Authorship: D.M.O., K.E.T., L.R.B. and R.S. designed the study; D.M.O., K.E.T., Z.W. and B.C. conducted the laboratory analyses; D.M.O. and L.R.B. conducted the statistical analyses; D.M.O., R.S. and K.E.T. wrote the first draft of the manuscript; all authors contributed to the final version of the manuscript. Ethics of buman subject participation: This study was conducted according to the guidelines laid down in the Declaration of Helsinki and all procedures involving human subjects were approved by the Alaska Area Institutional Review Board, the UAF Institutional Review Board, the Centers for Disease Control and Prevention, and the Yukon Kuskokwim Health Corporation Board of Directors.

\section{References}

1. Murphy NJ, Schraer CD, Thiele MC et al. (1995) Dietary change and obesity associated with glucose-intolerance in Alaska Natives. J Am Diet Assoc 95, 676-682.

2. Bersamin A, Zidenberg-Cherr S, Stern JS et al. (2007) Nutrient intakes are associated with adherence to a traditional diet among Yup'ik Eskimos living in remote Alaska Native communities: the CANHR study. Int J Circumpolar Health 66, 62-70.

3. Johnson JS, Nobmann ED, Asay E et al. (2009) Dietary intake of Alaska Native people in two regions and implications for health: the Alaska Native Dietary and Subsistence Food Assessment Project. Int J Circumpolar Health 68, 109-122.

4. Singleton R, Lescher R, Gessner BD et al. (2015) Rickets and vitamin $\mathrm{D}$ deficiency in Alaska native children. $J$ Pediatr Endocrinol Metab 28, 815-823.

5. Gessner BD, deSchweinitz E, Petersen KM et al. (1997) Nutritional rickets among breast-fed black and Alaska Native children. Alaska Med 39, 72-74, 87.

6. Luick B, Bersamin A \& Stern JS (2014) Locally harvested foods support serum 25-hydroxyvitamin D sufficiency in an indigenous population of Western Alaska. Int J Circumpolar Health 73, 10.3402/ijch.v73.22732.

7. Fohner AE, Wang Z, Yracheta J et al. (2015) Genetics, diet, and season are associated with serum 25-hydroxycholecalciferol concentration in a Yup'ik study population from southwestern Alaskaa. J Nutr 146, 318-325.
8. Kuhnlein HV, Receveur O, Soueida R et al. (2004) Arctic Indigenous Peoples experience the nutrition transition with changing dietary patterns and obesity. J Nutr 134, 1447-1453.

9. Egeland GM, Johnson-Down L, Cao ZR et al. (2011) Food insecurity and nutrition transition combine to affect nutrient intakes in Canadian arctic communities. J Nutr 141, 1746-1753.

10. Sharma S, Barr AB, Macdonald HM et al. (2011) Vitamin D deficiency and disease risk among aboriginal Arctic populations. Nutr Rev 69, 468-478.

11. Andersen S, Jakobsen A \& Laurberg P (2013) Vitamin D status in North Greenland is influenced by diet and season: indicators of dermal 25-hydroxy vitamin D production north of the Arctic Circle. Br J Nutr 110, 50-57.

12. Nielsen NO, Jorgensen ME, Friis H et al. (2014) Decrease in vitamin D status in the Greenlandic adult population from 1987-2010. PLoS One 9, e112949.

13. Rejnmark L, Jorgensen ME, Pedersen MB et al. (2004) Vitamin D insufficiency in Greenlanders on a westernized fare: ethnic differences in calcitropic hormones between Greenlanders and Danes. Calcif Tissue Int 74, 255-263.

14. Heller CA \& Scott EM (1967) The Alaska Dietary Survey, Environmental Health Series. Washington, DC: US Deparment of Health, Education and Welfare, Public Health Service, Nutrition and Metabolic Disease Section, Arctic Health Research Center.

15. Bersamin A, Luick BR, Ruppert E et al. (2006) Diet quality among Yup'ik Eskimos living in rural communities is low: the Center for Alaska Native Health Research pilot study. J Am Diet Assoc 106, 1055-1063.

16. Nash SH, Bersamin A, Kristal AR et al. (2012) Stable nitrogen and carbon isotope ratios indicate traditional and market food intake in an indigenous circumpolar population. J Nutr 142, 84-90.

17. O'Brien DM, Kristal AR, Jeannet MA et al. (2009) Red blood cell $\delta^{15} \mathrm{~N}$ : a novel biomarker of dietary eicosapentaenoic acid and docosahexaenoic acid intake. Am J Clin Nutr 89, 913-919.

18. O'Brien DM, Kristal AR, Nash SH et al. (2014) A stable isotope biomarker of marine food intake captures associations between $n-3$ fatty acid intake and chronic disease risk in a Yup'ik study population, and detects new associations with blood pressure and adiponectin. J Nutr 144, 706-713.

19. O'Brien DM (2015) Stable isotope ratios as biomarkers of diet for health research. Annu Rev Nutr 35, 565-594.

20. Parkinson AJ, Hennessy T, Bulkow L et al. (2013) The Alaska Area Specimen Bank: a tribal-federal partnership to maintain and manage a resource for health research. Int J Circumpolar Health 72, 20607.

21. Mohatt GV, Plaetke R, Klejka J et al. (2007) The Center for Alaska Native Health Research Study: a community-based participatory research study of obesity and chronic diseaserelated protective and risk factors. Int J Circumpolar Health 66, 8-18.

22. Nash SH, Kristal AR, Bersamin A et al. (2013) Carbon and nitrogen stable isotope ratios predict intake of sweeteners in a Yup'ik study population. J Nutr 143, 161-165.

23. Wilkinson MJ, Yai Y \& O'Brien DM (2007) Age-related variation in red blood cell stable isotope ratios $\left(\delta^{13} \mathrm{C}\right.$ and $\delta^{15} \mathrm{~N}$ ) from two Yupik villages in Southwest Alaska: a pilot study. Int J Circumpolar Health 66, 31-41.

24. Wang Z, Lin YS, Dickmann LJ et al. (2013) Enhancement of hepatic 4-hydroxylation of 25-hydroxyvitamin $\mathrm{D}_{3}$ through CYP3A4 induction in vitro and in vivo: implications for drug-induced osteomalacia. J Bone Miner Res 28, 1101-1116.

25. Lissner D, Mason RS \& Posen S (1981) Stability of vitamin D metabolites in human blood serum and plasma. Clin Chem 27, 773-774. 
26. Hollis BW (2008) Measuring 25-hydroxyvitamin D in a clinical environment: challenges and needs. Am J Clin Nutr 88, issue 2, 507S-510S.

27. Agborsangaya C, Toriola AT, Grankvist K et al. (2010) The effects of storage time and sampling season on the stability of serum 25-hydroxy vitamin $\mathrm{D}$ and androstenedione. Nutr Cancer 62, 51-57.

28. Institute of Medicine (2011) Dietary Reference Intakes for Calcium and Vitamin D [AC Ross, CL Taylor, AL Yaktine et al., editors]. Washington, DC: The National Academies Press.

29. Rosen CJ, Abrams SA, Aloia JF et al. (2012) IOM committee members respond to Endocrine Society vitamin D guideline. J Clin Endocrinol Metab 97, 1146-1152.

30. Nobmann ED, Byers T, Lanier AP et al. (1992) The diet of Alaska Native adults - 1987-1988. Am J Clin Nutr 55 1024-1032.

31. Holick MF, Binkley NC, Bischoff-Ferrari HA et al. (2011) Evaluation, treatment, and prevention of vitamin D deficiency: an Endocrine Society clinical practice guideline. J Clin Endocrinol Metab 96, 1911-1930.

32. Holick MF (2008) Vitamin D: a D-Lightful health perspective. Nutr Rev 66, 10 Suppl. 2, S182-S194.

33. El Hayek J, Egeland G \& Weiler H (2010) Vitamin D status of Inuit preschoolers reflects season and vitamin D intake. J Nutr 140, 1839-1845.

34. Sharma S, Hopping BN, Roache C et al. (2013) Nutrient intakes, major food sources and dietary inadequacies of Inuit adults living in three remote communities in Nunavut, Canada. J Hum Nutr Diet 26, 578-586.

35. Kolahdooz F, Barr A, Roache C et al. (2013) Dietary adequacy of vitamin $\mathrm{D}$ and calcium among Inuit and
Inuvialuit women of child-bearing age in Arctic Canada: a growing concern. PLoS One 8, e78987.

36. Webb AR, Kline L \& Holick MF (1988) Influence of season and latitude on the cutaneous synthesis of vitamin $\mathrm{D}_{3}$ : exposure to winter sunlight in Boston and Edmonton will not promote vitamin $\mathrm{D}_{3}$ synthesis in human skin. $J$ Clin Endocrinol Metab 67, 373-378.

37. Webb AR \& Engelsen O (2006) Calculated ultraviolet exposure levels for a healthy vitamin D status. Photochem Photobiol 82, 1697-1703.

38. Chaplin G \& Jablonski NG (2013) The human environment and the vitamin D compromise: Scotland as a case study in human biocultural adaptation and disease susceptibility. Hum Biol 85, 529-552.

39. Wagner CL \& Greer FR, American Academy of Pediatrics Section on B, et al. (2008) Prevention of rickets and vitamin $\mathrm{D}$ deficiency in infants, children, and adolescents. Pediatrics 122, 1142-1152.

40. Paterson CR \& Ayoub D (2015) Congenital rickets due to vitamin D deficiency in the mothers. Clin Nutr 34, 793-798.

41. Bersamin A, Luick BR, King IB et al. (2008) Westernizing diets influence fat intake, red blood cell fatty acid composition, and health in remote Alaskan Native communities in the center for Alaska Native health study. J Am Diet Assoc 108, 266-273.

42. Longnecker MP, Zhou H, Klebanoff MA et al. (2003) An unexpected distribution of sodium concentration in serum specimens stored for more than 30 years. Ann Epidemiol 13, 178-181. 